\title{
Measuring Commercial Bank Profitability: Proceed with Caution
}

\author{
R. Alton Gilbert and David C. Wheelock
}

\begin{abstract}
The federal tax code creates challenges for comparing the profit rates of different banks on a consistent basis. The earnings of banks that elect to operate under subchapter $S$ of the federal tax code are not subject to federal corporate income tax, but shareholders of these "S-banks" are taxed on their pro rata share of the entire earnings of the bank. The number of banks electing subchapter $S$ tax treatment has increased rapidly, especially among small banks. The authors use estimates of the federal corporate income tax that S-banks would pay if they were subject to the tax to show that the difference in the tax treatment of S-banks and other banks has a large impact on measures of U.S. banking system profitability. Further, the article shows that adjustment of S-bank earnings by estimates of federal income taxes to make them comparable with the earnings of other banks can markedly affect conclusions of studies that use net income as a measure of performance. Finally, the article shows that S-banks (even after their earnings are reduced by estimated federal taxes) tend to out-earn their peers; S-banks also tend to have higher earnings rates than their peers in the year before they elect S-bank status. (JEL G21, G28, H25)
\end{abstract}

Federal Reserve Bank of St. Louis Review, November/December 2007, 89(6), pp. 515-32.

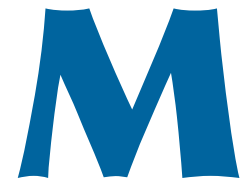

easures of after-tax rates of return, such as the return on average total assets (ROA) and the return on total equity (ROE), are widely used to assess the performance of firms, including commercial banks. Bank regulators and analysts have used ROA and ROE to assess industry performance and forecast trends in market structure-as inputs in statistical models to predict bank failures and mergers-and for a variety of other purposes where a measure of profitability is desired.

The usefulness of standard profit measures can be affected by tax laws and regulations, which are subject to occasional amendment and revision. Subchapter S of the federal tax code, for example, was established to benefit small businesses by granting them relief from the double taxation of corporate dividends. The dividends paid by most corporations are taxed twice-once at the firm level under the corporate income tax and again at the shareholder level under the personal income tax. However, the earnings of banks and other firms that elect subchapter $S$ tax treatment (S-corporations) are not subject to the federal corporate income tax. (However, shareholders of S-corporations are subject to personal income taxes on their pro rata share of the firm's entire earnings, including nondistributed retained earnings. Corporations not electing subchapter $\mathrm{S}$ status operate under subchapter $\mathrm{C}$ of the federal tax code-hereafter, C-corporations.)

Because the earnings of S-corporations are taxed differently from those of C-corporations, the profit rates of S- and C-corporations are not directly comparable on the basis of standard measures of after-tax rates of return.

R. Alton Gilbert is a former vice president and banking economics advisor and David C. Wheelock is an assistant vice president and economist at the Federal Reserve Bank of St. Louis. The authors thank Andrew Meyer and Rajdeep Sengupta for helpful comments. Craig Aubuchon and Daniel McDonald provided research assistance.

(C) 2007, The Federal Reserve Bank of St. Louis. Articles may be reprinted, reproduced, published, distributed, displayed, and transmitted in their entirety if copyright notice, author name(s), and full citation are included. Abstracts, synopses, and other derivative works may be made only with prior written permission of the Federal Reserve Bank of St. Louis. 
Recent growth in the number of banks that elect to operate under subchapter $S$ of the federal tax code has complicated the use of after-tax profit measures to assess trends in industry profitability and to compare rates of return across banks and over time. This article examines the consequences of the proliferation of S-banks for assessing the profitability of the U.S. banking industry. The quarterly Uniform Bank Performance Report (UBPR) produced by the Federal Financial Institutions Examination Council (FFIEC) provides hypothetical after-tax rate of return data for individual S-banks: That is, S-banks' rates of return are adjusted by an estimate of the federal corporate income tax that those banks would have had to pay if they were subject to the tax. ${ }^{1}$ The adjustment is quantitatively large for many banks, indicating that comparisons of S- and C-banks using standard after-tax profit measures can lead to erroneous conclusions. Because S-banks are more prevalent among smaller banks, comparison of average after-tax profit rates across groups of banks delineated by size is especially problematic unless differences in the tax treatment of S- and C-bank earnings are taken into account. This article shows quantitatively the impact of the differences in the tax treatment of S- and C-banks on measures of U.S. banking system profitability.

We find that the net profit rates of S-banks tend to exceed those of similarly sized C-banks, even after S-bank earnings are adjusted by the UBPR estimate of federal income taxes that they would have had to pay if they were subject to the corporate income tax. The UBPR adjustment does not account for any differences in how $\mathrm{S}$ - and C-banks are taxed by states, however, nor does it capture differences in how S- and C-banks are managed in response to the incentives they face because of how their earnings are taxed. We find that S-banks consistently have higher pre-tax earnings rates and net interest margins than Cbanks and tend to be more cost efficient. Further, we find that C-banks that became S-banks tended

\footnotetext{
1 Regulators use the UBPR for offsite surveillance of banks. Privatesector bank analysts also frequently use the report, which can be accessed at the web site of the FFIEC, an interagency body comprising the federal regulators of bank and thrift institutions. See www.ffiec.gov.
}

to have higher profit rates in the year before they changed status than other C-banks, suggesting that S-bank status alone cannot fully account for the higher average adjusted profit rates of S-banks.

Because one cannot meaningfully compare the earnings of S- and C-banks on the basis of standard after-tax profit rates, some analysts use pre-tax profit measures to evaluate the performance of banks and in statistical models that include a profit measure. Presumably banks seek to maximize after-tax profits rather than pre-tax profits, however, and some strategies for maximizing after-tax profits can result in relatively low pre-tax earnings rates. For example, some banks hold large amounts of securities whose interest payments are exempt from taxation at the federal, state, and/or local levels. All else equal, a bank that holds a large amount of tax-advantaged securities may have a relatively low pre-tax rate of return but a relatively high after-tax rate of return. Hence, comparison of pre-tax profit rates can give a misleading view of bank performance. The UBPR includes an adjustment to banks' pre-tax income for tax-exempt earnings. This article investigates how large an impact this adjustment has on pretax bank earnings rates.

In summary, the federal tax code creates challenges for measuring the profit rates of banks on a consistent basis across banks and across time. The UBPR, however, provides two measures of bank profits designed to permit such comparisons: (i) pre-tax income adjusted for earnings on taxadvantaged securities and (ii) after-tax income adjusted for the federal corporate income tax that S-banks would have had to pay if they were Cbanks. While these measures can be useful, this article suggests that analysts should proceed with caution when using any measure of bank profitability.

The following section illustrates the implications of subchapter $\mathrm{S}$ tax treatment for after-tax measures of bank earnings and for shareholder income. Subsequently, we examine the growth in the number of S-banks across different groups sorted by asset size and show how the proliferation of S-banks has affected measures of banking industry profitability. We then examine how conclusions about the viability of small, community 


\section{Table 1}

\begin{tabular}{|c|c|c|}
\hline & C-bank & S-bank \\
\hline Total assets & $\$ 50,000,000$ & $\$ 50,000,000$ \\
\hline Pre-tax income & $1,000,000$ & $1,000,000$ \\
\hline Federal corporate income tax & 300,000 & 0 \\
\hline Net income after tax & 700,000 & $1,000,000$ \\
\hline $\begin{array}{l}\text { Adjustment to the net income of the S-bank for taxes it would pay } \\
\text { if taxed as a C-bank }\end{array}$ & & $-300,000$ \\
\hline UBPR tax-adjusted net income of bank & 700,000 & 700,000 \\
\hline Dividends to shareholders & 210,000 & 300,000 \\
\hline Taxes paid by shareholders & 63,000 & 300,000 \\
\hline \multicolumn{3}{|l|}{ Returns to shareholders } \\
\hline Retained earnings & 490,000 & 700,000 \\
\hline Plus dividends & 210,000 & 300,000 \\
\hline Minus taxes on dividends & 63,000 & 300,000 \\
\hline Increase in the net worth of shareholders & 637,000 & 700,000 \\
\hline
\end{tabular}

banks can be substantially affected by whether or not one adjusts S-bank earnings for estimated federal taxes. Further, we examine differences in the financial characteristics of S- and C-banks and explore the implications of using pre-tax earnings as an alternative to after-tax profits.

\section{HOW THE TAXATION OF S-BANK PROFITS AFFECTS BANK RETURNS AND SHAREHOLDER INCOME}

Subchapter S enables small firms to avoid double taxation on distributed earnings without sacrificing the advantages of limited liability. Although the earnings of ordinary (subchapter C) corporations are subject to the federal corporate income tax, the earnings of subchapter S corporations are exempt from the tax. However, shareholders of subchapter S corporations are subject to personal income tax on their pro rata share of the entire earnings of the corporation, not just on dividends. The example below illustrates how the shareholders of S-banks benefit from the elimination of double taxation of dividends.
Consider the hypothetical C- and S-banks with financial data given in Table 1. Each bank has total assets of $\$ 50$ million and pre-tax income of $\$ 1$ million. In addition, each bank pays 30 percent of its net after-tax income as dividends to its shareholders. ${ }^{2}$ To simplify the illustration, we assume that the state corporate income tax is zero for these banks. Further, we assume that the shareholders of each bank have a marginal tax rate of 30 percent and that the federal income tax rate for corporations is also 30 percent.

The C-bank pays federal income tax of $\$ 300,000$, whereas the S-bank pays no federal income tax. The C-bank reports net after-tax income of $\$ 700,000$, and the S-bank reports net after-tax income of $\$ 1,000,000$. Thus, the standard ROA of the C-bank is 1.4 percent, whereas the standard ROA of the S-bank is 2 percent. This difference in ROA is due entirely to the difference in how the earnings of the two banks are taxed, because their pre-tax earnings and their total assets are the same. The UBPR would report the adjusted net income of the S-bank as $\$ 700,000$, the

2 In practice, S-banks tend to have higher dividend payout rates than C-banks. We assume equal payout rates in our example for simplicity and to focus on the implications of the different federal corporate income tax rates for S- and C-banks. 


\section{Figure 1}

\section{Number of Banks Electing Subchapter-S and -C Status}

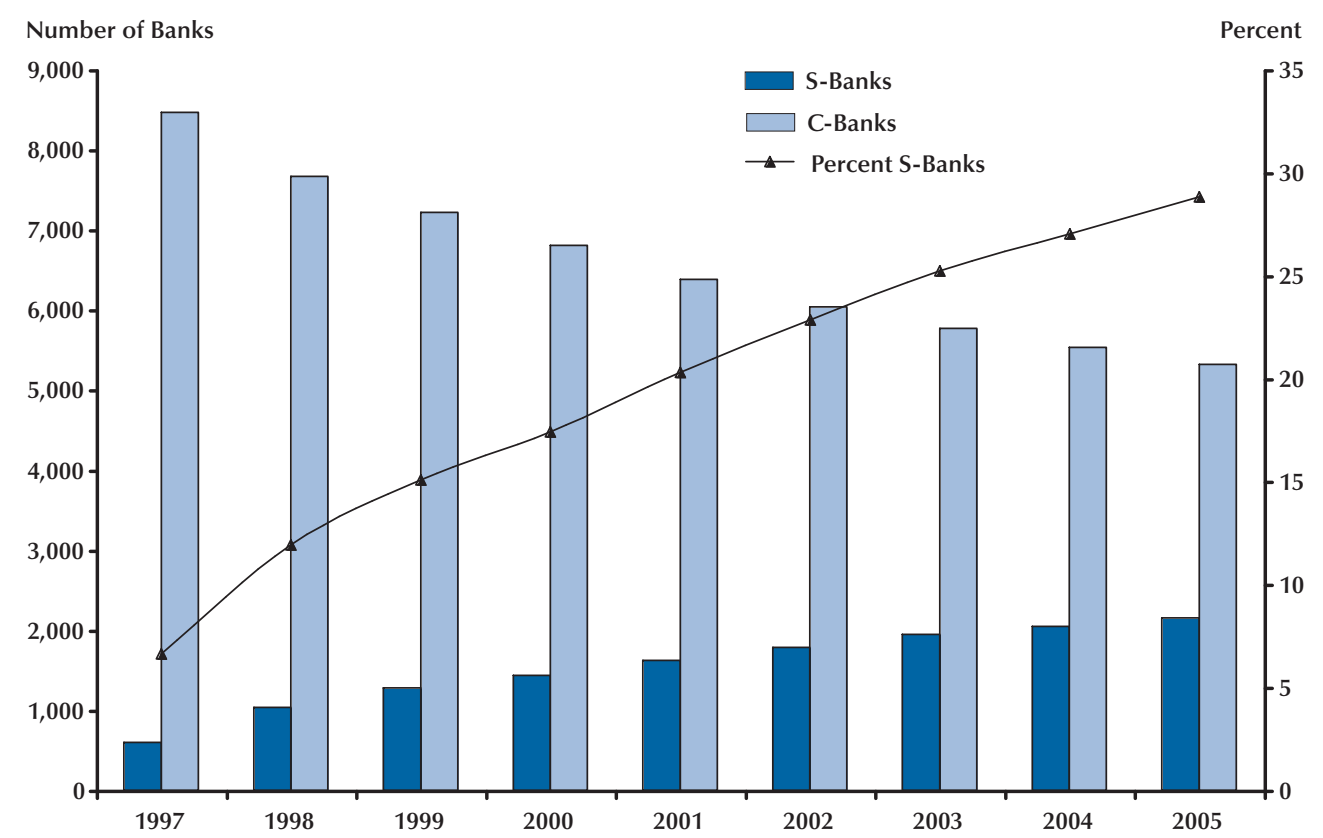

same as the net income of the C-bank, and the adjusted ROA of each bank would be 1.4 percent. $^{3}$

The C-bank pays dividends of $\$ 210,000$, whereas the S-bank pays dividends of $\$ 300,000$. With a marginal tax rate of 30 percent, the shareholders of the C-bank pay income tax of $\$ 63,000$ on their dividends, whereas the shareholders of the S-bank pay income tax of $\$ 300,000$ because they are taxed on the full earnings of the bank, not just on the dividends they receive.

Positive profits in the current year increase the net worth of the shareholders of both the Cbank and S-bank. The increase in net worth is higher for the shareholders of the S-bank by $\$ 63,000$, which is the amount of tax that the shareholders of the C-bank pay on their dividends. Of course, these magnitudes would differ under other possible assumptions.

3 UBPR adjusts an S-banks' net income by subtracting from pre-tax income the UBPR estimate of the federal corporate income tax that the S-bank would have had to pay if it were taxed as a C-bank, which creates a measure comparable to C-banks' adjusted net income, which equals after-tax net income.

\section{The Proliferation of S-Banks}

Congress created subchapter $\mathrm{S}$ of the federal tax code in 1958, but commercial banks have been permitted to elect subchapter $S$ status only since January 1997. The number of commercial banks electing subchapter $S$ tax treatment has since risen rapidly. Figure 1 illustrates the growth in the number and percentage of banks electing S-status over time. The number of S-banks increased from 601 banks (representing 6.6 percent of the industry) at year-end 1997 to 2,155 banks (representing 28.8 percent of the industry) at year-end 2005.

Subchapter S corporations are limited to a maximum of 100 shareholders, which precludes many larger banks from electing S-status. ${ }^{4}$ Hence, S-banks are concentrated among smaller banks. Table 2 reports the relative number and asset

\footnotetext{
4 See Landau (2005) and www.s-corp.org/asp/products/ product_3_4.asp for information about the history of subchapter $S$ and current requirements for election of $S$ status.
} 


\section{Table 2}

\section{S-Bank Presence By Bank Size Group, 2005}

\begin{tabular}{|c|c|c|c|c|c|c|}
\hline \multirow[b]{2}{*}{ Bank size group } & \multicolumn{3}{|c|}{ Number of banks } & \multicolumn{3}{|c|}{ Assets (in thousands) } \\
\hline & All banks & S-banks & Percent S-banks & All banks & S-banks & Percent S-banks \\
\hline Greater than $\$ 1$ billion & 460 & 26 & 5.7 & $\$ 7,190,934,374$ & $\$ 37,148,074$ & 0.5 \\
\hline$\$ 300$ million to $\$ 1$ billion & 1,094 & 186 & 17.0 & $525,041,331$ & $85,106,377$ & 16.2 \\
\hline$\$ 100$ million to $\$ 300$ million & 2,279 & 654 & 28.7 & $380,418,078$ & $105,267,783$ & 27.7 \\
\hline$\$ 50$ million to $\$ 100$ million & 1,585 & 616 & 38.9 & $112,932,985$ & $43,362,442$ & 38.4 \\
\hline Less than $\$ 50$ million & 1,480 & 597 & 40.3 & $44,274,181$ & $19,095,383$ & 43.1 \\
\hline All groups & 6,898 & 2,079 & 30.1 & $8,253,600,949$ & $289,980,059$ & 3.5 \\
\hline
\end{tabular}

NOTE: Data include only those banks in peer groups 1 through 15 of the Uniform Bank Performance Report. Size groups are based on total end-of-year assets.

holdings of S-banks for five size groups, as well as across all groups, as of December $31,2005 .^{5}$ For example, S-banks accounted for less than 6 percent of banks with $\$ 1$ billion or more of assets and just 0.5 percent of the total assets of banks with more than $\$ 1$ billion of assets. By contrast, S-banks accounted for over 40 percent of banks and over 43 percent of the total assets of all banks with less than $\$ 50$ million of assets.

\section{EFFECTS OF THE TAX TREATMENT OF S-BANKS ON MEASURES OF BANK INCOME}

This section examines how the proliferation of banks electing $\mathrm{S}$ status has affected aggregate measures of banking industry profitability. ${ }^{6}$ Figures 2 and 3 plot annual data from 1996 to 2005 on median after-tax ROA and ROE, respectively, for large and small banks; here, large banks are those with more than $\$ 1$ billion of assets and small banks are those with less than $\$ 1$ billion of

5 The data reported in Table 2 are for all banks in peer groups 1 through 15 of the UBPR. These peer groups include all U.S. commercial banks except those chartered during the most recent five years. Including such banks would raise the total number of Sbanks to 2,155. Peer groups 1 through 15 also exclude credit card specialty banks, bankers' banks, and thrifts. See the March 2006 UBPR user's guide (FFIEC, 2006, Section II: Technical Information).

6 Hein, Koch, and MacDonald (2005) present similar information through 2002. assets. The median after-tax profit rates of large banks exceeded those of small banks throughout the period and increased relative to those of small banks after $2000 .^{7}$

In addition to the standard ROA and ROE measures, the dashed lines in Figures 2 and 3 also show median earnings rates based on the alternative measure in which the earnings rates of S-banks are reduced by the UBPR estimates of the tax that they would have had to pay if subject to the federal corporate income tax. The median values of ROA adjusted and ROE adjusted shown in the figures are calculated using the standard ROA and ROE measures for C-banks and the measures that are adjusted for estimated federal corporate income taxes for S-banks. ${ }^{8}$ Because few large banks are S-banks, the S-bank adjustment for estimated taxes has only a small effect on the median profit rates of banks with assets of at least $\$ 1$ billion. However, for small banks, the impact of the adjustment is large and has been growing

7 Figures 2 and 3 report median profit rates because extreme values distort mean profit rates. Comparisons such as those in Figures 2 and 3 can be sensitive to how one distinguishes "large" and "small" banks. For example, Bassett and Brady (2001) find that between 1985 and 2000, small banks (defined as those outside the largest 1,000 banks) consistently had higher average earnings rates than the largest 100 U.S. banks. Bassett and Brady do not use the UBPR data on net income adjusted for the tax treatment of S-banks.

8 See FFIEC (2006, Section II, “Technical Information,” p. 4) for information about the adjusted measure of after-tax earnings of S-banks for estimated income taxes. This document is available at www.ffiec.gov/ubprguide.htm. 
Figure 2

ROA With and Without S-Bank Adjustment

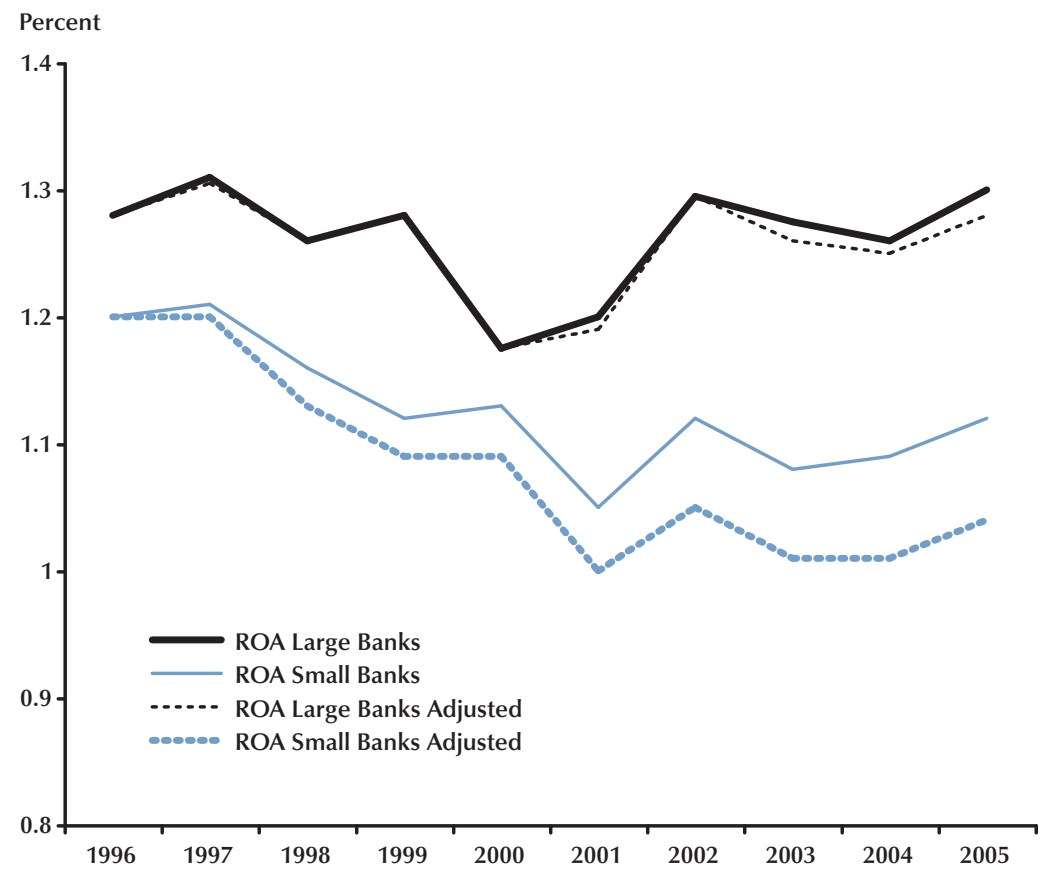

Table 3

Median Return on Assets (ROA) and Return on Equity (ROE) for Banks Grouped by Size and Tax Status, 2005

\begin{tabular}{lccccc} 
& \multicolumn{3}{c}{ All banks } \\
\cline { 2 - 6 } Bank size group & Number & ROA & $\begin{array}{c}\text { ROA } \\
\text { adjusted }\end{array}$ & $\begin{array}{c}\text { ROE } \\
\text { adjusted }\end{array}$ \\
\hline More than \$1 billion & 450 & 1.30 & 1.28 & 13.87 & 13.62 \\
\$300 million to \$1 billion & 1,071 & 1.21 & 1.16 & 13.27 & 12.84 \\
\$100 to \$300 million & 2,250 & 1.17 & 1.08 & 11.77 & 11.01 \\
\$50 to \$100 million & 1,560 & 1.10 & 0.99 & 10.55 & 9.52 \\
Less than $\$ 50$ million & 1,429 & 0.99 & 0.89 & 8.51 & 7.64
\end{tabular}

NOTE: Includes only those banks in peer groups 1 through 15 of the Uniform Bank Performance Report. ROA adjusted: ROA with adjustment for imputed taxes; for all banks, this is the median ROA across all banks, where ROA for S-banks is adjusted for imputed taxes. ROE adjusted: ROE with adjustment for imputed taxes; for all banks, ROE adjusted is the median ROE across all banks, where ROE for S-banks is adjusted for imputed taxes. Bank size groups are based on total end-of-year assets. 


\section{Figure 3}

\section{ROE With and Without S-Bank Adjustment}

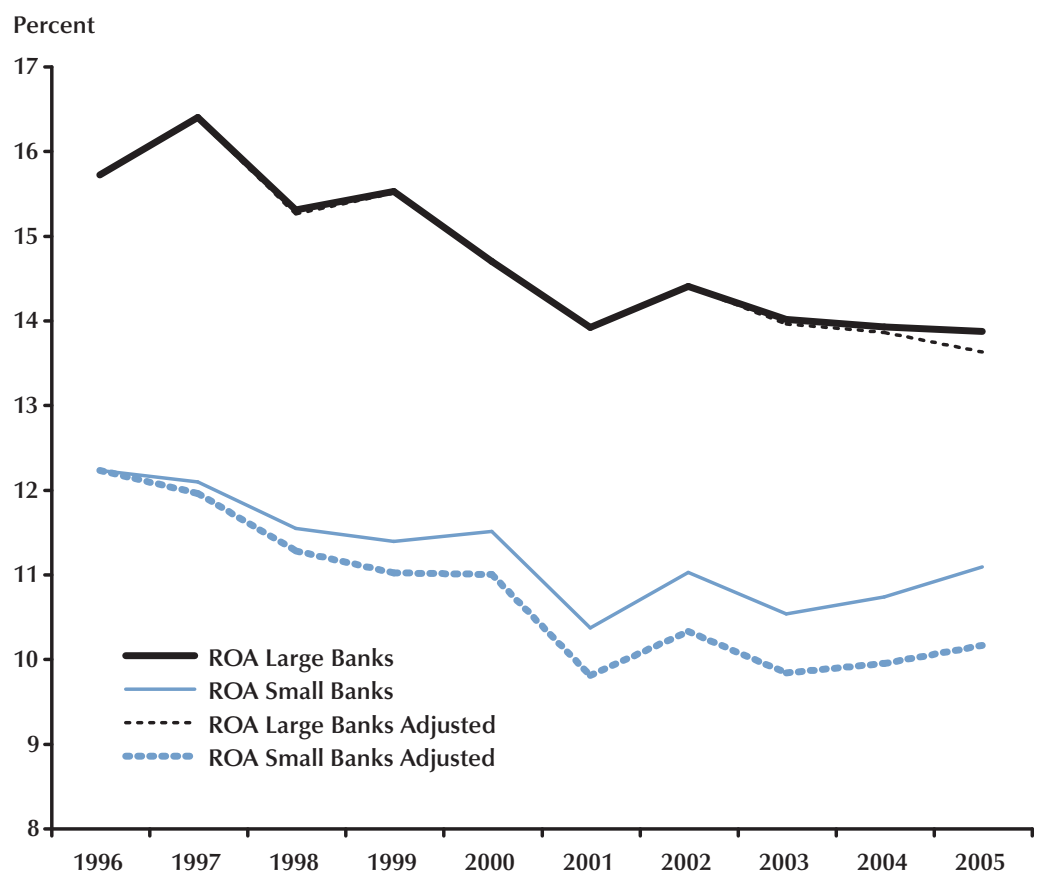

\section{Table 3, cont'd}

\begin{tabular}{|c|c|c|c|c|c|c|c|}
\hline \multicolumn{3}{|c|}{ C-banks } & \multicolumn{5}{|c|}{ S-banks } \\
\hline Number & ROA & ROE & Number & ROA & $\begin{array}{c}\text { ROA } \\
\text { adjusted }\end{array}$ & ROE & $\begin{array}{c}\text { ROE } \\
\text { adjusted }\end{array}$ \\
\hline 426 & 1.28 & 13.62 & 24 & 1.78 & 1.34 & 19.07 & 13.78 \\
\hline 896 & 1.14 & 12.55 & 175 & 1.74 & 1.25 & 19.64 & 14.25 \\
\hline 1,607 & 1.05 & 10.41 & 643 & 1.63 & 1.18 & 17.47 & 12.49 \\
\hline 952 & 0.94 & 8.80 & 608 & 1.49 & 1.08 & 15.15 & 10.91 \\
\hline 848 & 0.82 & 6.94 & 581 & 1.37 & 0.97 & 12.41 & 8.88 \\
\hline
\end{tabular}


over time as the number of S-banks has risen. Moreover, the earnings gap between large and small banks based on the adjusted earnings measures has been getting wider over time.

Table 3 presents information on the median after-tax profit rates (ROA and ROE) of commercial banks of various size groups for 2005. The table also reports median adjusted ROA and ROE (calculated as in Figures 2 and 3).

Only 24 banks with $\$ 1$ billion or more of assets elected S-bank status in 2005; accordingly, for all banks with total assets greater than $\$ 1$ billion, the differences between median ROA and median adjusted ROA and between median ROE and median adjusted ROE are small. The median ROA of commercial banks with at least $\$ 1$ billion of assets is 1.30 percent and median ROE is 13.87 percent, whereas median adjusted ROA is 1.28 percent and median adjusted ROE is 13.62 percent.

Tax adjustment of S-bank earnings has a larger impact on group median earnings rates for smaller banks. For the smallest banks-those with no more than $\$ 50$ million of assets-median ROA drops from 0.99 percent to 0.89 percent and median ROE drops from 8.51 percent to 7.64 percent when S-bank profit rates are adjusted to include imputed taxes. Hence, the exemption of S-banks from the corporate income tax has an especially large impact on median after-tax earnings rates for groups consisting of small banks.

In addition to showing median profit rates across all banks in each size group, Table 3 reports data for C- and S-banks separately. For S-banks, we report median values of both unadjusted and adjusted ROA and ROE. The median values of ROA and ROE for S-banks are considerably larger than those for C-banks, with much of the differences accounted for by the different tax treatment of S- and C-banks. Adjusting ROA and ROE to include the UBPR estimate of federal income taxes has a large impact on median earnings rates for S-banks across all size ranges. For example, for the S-banks with less than $\$ 50$ million of assets, the adjustment reduces median ROA from 1.37 percent to 0.97 percent and median ROE from 12.41 percent to 8.88 percent. Clearly, the absence of federal corporate income taxes on S-bank earn- ings has a large impact on their measured aftertax rates of return, indicating that caution is warranted when comparing after-tax rates of return of S- and C-banks-or of groups of banks that include both $\mathrm{S}$ - and C-banks. ${ }^{9}$

\section{IMPLICATIONS OF THE ADJUSTMENT OF S-BANK PROFITS FOR ECONOMIC RESEARCH: AN EXAMPLE INVOLVING THE VIABILITY OF SMALL BANKS}

The total number of small banks and their share of industry assets have been falling in recent years. This trend has led many analysts to question whether small, "community" banks remain viable in today's banking environment. Advances in communications and information-processing technology have eroded the benefits of close proximity and local ties that traditionally enabled community banks to provide financial services profitably to small firms and other local borrowers. In addition, the removal of state and federal restrictions on branch banking has put further strain on many community banks by exposing them to increased competition.

Conclusions about the viability of community banks have often been based on comparisons of the profit rates of small and large banks. For example, DeYoung, Hunter, and Udell (2004) compare after-tax rates of return (ROA and ROE) of community and rural banks with those of mid-size banks (defined as banks with assets between \$1 billion and $\$ 10$ billion of assets) and large banks (defined as banks with at least $\$ 10$ billion of assets). Their data on bank profits are not adjusted for the corporate income tax that S-banks would pay if they were taxed like C-banks.

DeYoung, Hunter, and Udell (2004) show that in 2001, the average ROA of "best practice"

\footnotetext{
9 Hein, Koch, and MacDonald (2005) and Keeton, Harvey, and Willis (2003) also note that the growing number of banks electing $\mathrm{S}$ status distorts comparison of after-tax rates of return across banks and especially comparisons between groups of large and small banks.
} 


\section{Table 4}

\section{Implication of S-bank Adjustment for Mean ROA and ROE of Best- and Worst-Practice Banks, 2005}

\begin{tabular}{|c|c|c|c|c|c|c|c|c|}
\hline & \multicolumn{4}{|c|}{ ROA } & \multicolumn{4}{|c|}{ ROE } \\
\hline & \multicolumn{2}{|c|}{ Above median ROE } & \multicolumn{2}{|c|}{ Below median ROE } & \multicolumn{2}{|c|}{ Above median ROE } & \multicolumn{2}{|c|}{ Below median ROE } \\
\hline & Unadjusted & Adjusted & Unadjusted & Adjusted & Unadjusted & Adjusted & Unadjusted & Adjusted \\
\hline Large community banks & 1.55 & 1.43 & 0.94 & 0.92 & 17.95 & 16.55 & 9.36 & 9.24 \\
\hline Medium community banks & 1.60 & 1.36 & 0.89 & 0.87 & 17.87 & 15.30 & 8.37 & 8.18 \\
\hline Small community banks & 1.52 & 1.22 & 0.71 & 0.67 & 15.39 & 12.36 & 5.68 & 5.45 \\
\hline Rural community banks & 1.45 & 1.19 & 0.60 & 0.57 & 15.10 & 12.37 & 4.65 & 4.46 \\
\hline Mean value for large banks & \multicolumn{4}{|c|}{1.32} & \multicolumn{4}{|c|}{14.14} \\
\hline
\end{tabular}

NOTE: Includes only those banks in peer groups 1 through 15 of the Uniform Bank Performance Report. Data exclude banks with ROA among the largest or smallest 1 percent of observations.

community banks exceeded the average ROA of mid-size and large banks, where "best-practice" banks are defined as those with an ROE exceeding the median for their asset-size group. In addition, these authors show that the average ROE of bestpractice community banks with at least $\$ 100$ million of assets also exceeded average ROE for mid-size and large banks. The authors conclude that these and other comparisons strongly suggest that the "community bank business model is economically viable," though they also note that many community banks are not operating profitably or at an efficient scale (p. 122).

Table 4 updates and extends the analysis of DeYoung, Hunter, and Udell (2004) using data for 2005. The table reports mean values of ROA and ROE for three groups of community banks based on asset size and for all community banks headquartered in rural areas (i.e., outside of metropolitan statistical areas). As in DeYoung, Hunter, and Udell (2004), we define large community banks as those with assets between $\$ 500$ million and $\$ 1$ billion of assets, medium community banks as those with assets between $\$ 100$ million and $\$ 500$ million of assets, and small community banks as those with assets less than $\$ 100$ million. We identify large banks as those with total assets in excess of $\$ 1$ billion. For each group, we report separate means for banks with ROE exceeding the group median and for those with ROE below the group median. Further, we report means based on the standard after-tax ROA and ROE measures and for data using the tax-adjusted Sbank measure. ${ }^{10}$

As shown in Table 4, for each group of community banks the mean values of unadjusted ROA and ROE for the best-practice banks exceed those for large banks-where, again, best-practice banks are defined as those with ROE above the median for their group and large banks are defined as those with assets in excess of $\$ 1$ billion. Among large community banks, for example, best-practice banks have a mean ROA of 1.55 percent, compared with a mean of 1.32 percent for large banks. Among rural community banks, best-practice banks have a mean ROA of 1.45 percent. However, the group means are substantially reduced if one adjusts S-bank earnings rates to include estimates of their hypothetical federal tax liability. For example, among large community banks, the mean adjusted ROA of best-practice banks is 1.43 percent, whereas among rural community banks, the mean adjusted ROA of best-practice

\footnotetext{
${ }^{10}$ Our data are from the UBPR and include all banks in peer groups 1 through 15. However, we omitted banks with extreme values of ROA (those in the upper-most or smallest 1 percent tails of the distribution) to eliminate outliers and some banks that appear to have been misclassified in the UBPR.
} 
banks is 1.19 percent. Further, among both small and rural community banks, the mean values of adjusted ROA and adjusted ROE for best-practice banks are lower than the overall means for large banks. Of course, these results do not necessarily imply that small community banks and rural banks are not viable. A definitive answer to the viability question would require a full accounting of the costs and benefits of electing S-bank tax treatment, which include not only the corporate and personal income tax issues, but also the implications for growth associated with legal limits on the number of shareholders an S-bank may have. However, the analysis here does show that conclusions about the profitability of banks of different sizes, and hence about the viability of small banks, can be markedly affected by whether or not one adjusts rate of return measures to include estimates of the federal corporate income taxes that S-banks would pay if subject to that tax.

\section{A COMPARISON OF S- AND C-BANK CHARACTERISTICS}

The UBPR tax adjustment of S-bank profits closes much of the gap between the after-tax profit rates of S- and C-banks of similar asset size. However, for most size groups it does not close the gap entirely. For all years from 1997 to 2005, we find that even with the imputation for federal corporate income taxes, S-banks tend to have higher adjusted rates of return than do C-banks. Table 5 presents information for 2005. For banks in the same asset-size group, the means of adjusted ROA and adjusted ROE of S-banks are higher than those of C-banks. The $p$-values shown below the differences in the mean profit rates of S-banks and C-banks in the bottom panel of Table 5 indicate that these differences are statistically significant for banks with assets of less than $\$ 1$ billion. ${ }^{11}$

\footnotetext{
${ }^{11}$ The information reported in Table 5 is based on data for all commercial banks assigned to peer groups 1 through 15 in the UBPR except those with values for ROA among the upper or lower 1 percent in a given year. By dropping banks with extreme values of ROA, we avoided including observations with implausible values, some of which were for banks that appeared to be misclassified in the UBPR.
}

We made similar comparisons for other years and obtained results that are similar to those for 2005, except as noted below. ${ }^{12}$

There are several possible explanations for why the tax-adjusted earnings rates of S-banks tend to exceed the earnings rates of C-banks. The UBPR adjustment to the net income of S-banks does not take into account any differences in the applicability of state corporate income or other taxes between S- and C-banks. In addition, this report makes no attempt to adjust profit measures for differences in the incentives that S- and Cbanks face in the management of their revenues and expenses because of the differences in how their income is taxed. The adequacy of the UBPR net income adjustment has implications for studies involving bank profit rates, such as those addressing the viability of community banks. For example, if the adjustment is too small, then the differences between the adjusted and unadjusted profit measures for small banks shown in Table 4 understate the true differences.

\section{Comparison of Mean Values of Various Financial Ratios Across S- and C-Banks}

Aside from the possibility that the UBPR tax adjustment of S-bank earnings is incomplete, S-banks might have higher average earnings rates than similar-size C-banks because of superior operating efficiency. This section compares Sand C-banks on the basis of various financial characteristics in an effort to understand better why S-bank earnings rates tend to exceed those of C-banks.

We compare S- and C-bank performance on measures of pre-tax net operating income (as a percentage of average total assets), net interest income, net non-interest income, and cost efficiency. ${ }^{13}$ As shown in Table 5, we find that Sbanks consistently have higher pre-tax profit rates

\footnotetext{
${ }^{12}$ For banks with assets between $\$ 300$ million and $\$ 1$ billion, the difference is statically significant in some years between 1997 and 2004. For banks with less than $\$ 300$ million, the difference is statically significant in every year.

13 See Harvey and Padget (2000) for additional discussion of the implications of S-status election for commercial banks and evidence on differences in the characteristics and performance of S- and C-banks during 1997-99.
} 


\section{Table 5}

Mean Values of Various Performance Measures, 2005

S-Banks

\begin{tabular}{lccccccc} 
& $\begin{array}{c}\text { ROA } \\
\text { Bdjusted }\end{array}$ & $\begin{array}{c}\text { ROE } \\
\text { adjusted }\end{array}$ & $\begin{array}{c}\text { Pre-tax op. } \\
\text { profit/assets }\end{array}$ & $\begin{array}{c}\text { Op. profit + } \\
\text { personnel/ } \\
\text { assets }\end{array}$ & $\begin{array}{c}\text { Net } \\
\text { interest } \\
\text { margin }\end{array}$ & $\begin{array}{c}\text { Net } \\
\text { non-interest } \\
\text { margin }\end{array}$ & $\begin{array}{c}\text { Cost } \\
\text { efficiency }\end{array}$ \\
\hline More than \$1 billion & 1.35 & 15.20 & 2.02 & 3.74 & 4.31 & -1.80 & 56.80 \\
\$300 million to \$1 billion & 1.24 & 14.06 & 1.79 & 3.65 & 4.45 & -2.03 & 58.27 \\
\$100 to \$300 million & 1.18 & 12.80 & 1.69 & 3.51 & 4.44 & -2.17 & 60.15 \\
\$50 to \$100 million & 1.09 & 11.20 & 1.56 & 3.37 & 4.37 & -2.29 & 62.65 \\
Less than \$50 million & 0.99 & 9.31 & 1.42 & 3.32 & 4.40 & -2.47 & 66.32
\end{tabular}

\section{C-Banks}

\begin{tabular}{lccccccc} 
Bank size group & ROA & ROE & $\begin{array}{c}\text { Pre-tax op. } \\
\text { profit/assets }\end{array}$ & $\begin{array}{c}\text { Op. profit }+ \\
\text { personnel/ } \\
\text { assets }\end{array}$ & $\begin{array}{c}\text { Net } \\
\text { interest } \\
\text { margin }\end{array}$ & $\begin{array}{c}\text { Net } \\
\text { non-interest } \\
\text { margin }\end{array}$ & $\begin{array}{c}\text { Cost } \\
\text { efficiency }\end{array}$ \\
\hline More than \$1 billion & 1.27 & 13.76 & 1.93 & 3.40 & 3.89 & -1.42 & 54.98 \\
\$300 million to \$1 billion & 1.17 & 12.70 & 1.73 & 3.41 & 4.21 & -1.92 & 58.56 \\
\$100 to \$300 million & 1.06 & 10.85 & 1.53 & 3.28 & 4.33 & -2.20 & 62.01 \\
\$50 to \$100 million & 0.94 & 8.95 & 1.33 & 3.18 & 4.34 & -2.46 & 66.91 \\
Less than \$50 million & 0.82 & 6.96 & 1.11 & 3.18 & 4.35 & -2.67 & 76.62
\end{tabular}

Difference Between C-Banks and S-Banks (mean and $p$-value for hypothesis tests)

\begin{tabular}{|c|c|c|c|c|c|c|c|}
\hline Bank size group & ROA* & ROE* & $\begin{array}{l}\text { Pre-tax op. } \\
\text { profit/assets }\end{array}$ & $\begin{array}{l}\text { Op. profit + } \\
\text { personnel/ } \\
\text { assets }\end{array}$ & $\begin{array}{c}\text { Net } \\
\text { interest } \\
\text { margin }\end{array}$ & $\begin{array}{c}\text { Net } \\
\text { non-interest } \\
\text { margin }\end{array}$ & $\begin{array}{c}\text { Cost } \\
\text { efficiency }\end{array}$ \\
\hline More than $\$ 1$ billion & $\begin{array}{r}-0.07 \\
0.32\end{array}$ & $\begin{array}{r}-1.45 \\
0.20\end{array}$ & $\begin{array}{r}-0.09 \\
0.33\end{array}$ & $\begin{array}{r}-0.34 \\
0.07\end{array}$ & $\begin{array}{r}-0.42 \\
0.04\end{array}$ & $\begin{array}{l}0.38 \\
0.02\end{array}$ & $\begin{array}{r}-1.82 \\
0.34\end{array}$ \\
\hline$\$ 300$ million to $\$ 1$ billion & $\begin{array}{r}-0.07 \\
0.05\end{array}$ & $\begin{array}{r}-1.34 \\
0.00\end{array}$ & $\begin{array}{r}-0.06 \\
0.19\end{array}$ & $\begin{array}{r}-0.24 \\
0.02\end{array}$ & $\begin{array}{r}-0.24 \\
0.01\end{array}$ & $\begin{array}{l}0.11 \\
0.06\end{array}$ & $\begin{array}{l}0.29 \\
0.38\end{array}$ \\
\hline$\$ 100$ to $\$ 300$ million & $\begin{array}{r}-0.12 \\
0.00\end{array}$ & $\begin{array}{r}-1.97 \\
0.00\end{array}$ & $\begin{array}{r}-0.16 \\
0.00\end{array}$ & $\begin{array}{r}-0.23 \\
0.00\end{array}$ & $\begin{array}{r}-0.11 \\
0.02\end{array}$ & $\begin{array}{r}-0.03 \\
0.27\end{array}$ & $\begin{array}{l}1.85 \\
0.00\end{array}$ \\
\hline$\$ 50$ to $\$ 100$ million & $\begin{array}{r}-0.16 \\
0.00\end{array}$ & $\begin{array}{r}-2.24 \\
0.00\end{array}$ & $\begin{array}{r}-0.23 \\
0.00\end{array}$ & $\begin{array}{r}-0.19 \\
0.00\end{array}$ & $\begin{array}{r}-0.03 \\
0.30\end{array}$ & $\begin{array}{r}-0.18 \\
0.00\end{array}$ & $\begin{array}{l}4.26 \\
0.00\end{array}$ \\
\hline Less than $\$ 50$ million & $\begin{array}{r}-0.18 \\
0.00\end{array}$ & $\begin{array}{r}-2.48 \\
0.00\end{array}$ & $\begin{array}{r}-0.31 \\
0.00\end{array}$ & $\begin{array}{r}-0.14 \\
0.04\end{array}$ & $\begin{array}{r}-0.05 \\
0.23\end{array}$ & $\begin{array}{r}-0.19 \\
0.00\end{array}$ & $\begin{array}{r}10.30 \\
0.04\end{array}$ \\
\hline
\end{tabular}

NOTE: ROA* (ROE*): Difference between mean ROA (ROE) of C-banks and mean adjusted ROA (ROE) for S-banks; $p$-values for the hypothesis test are below the differences. Sample includes only those banks in peer groups 1 through 15 of the Uniform Bank Performance Report. Data exclude banks with ROA among the largest or smallest 1 percent of observations. Bank size groups are based on total end-of-period assets. 
than C-banks of similar size, and the differences are statistically significant for banks with less than $\$ 300$ million of assets. ${ }^{14} \mathrm{~S}$-banks also tend to have higher net interest margins (i.e., net interest income divided by average earning assets) than C-banks, as reflected in higher mean values across all size groups. ${ }^{15}$ For 2005 , the differences in the means are statistically significant for banks in the three largest size groups. However, for banks with less than $\$ 100$ million of assets, we cannot reject the hypothesis that mean values of net interest margins of S- and C-banks are equal. Although for other years we also find that S-banks tend to have higher mean net interest margins than C-banks, the differences in the means are often not statistically significant, especially for the smallest banks.

We also compare non-interest margins (i.e., net non-interest income divided by average total assets) across S- and C-banks. For banks with less than $\$ 100$ million of assets, S-banks consistently have higher mean non-interest margins than C-

banks. However, for larger banks, especially those with more than $\$ 300$ million of assets, we find that S-banks tend to have lower mean non-interest margins than C-banks, and the difference is statistically significant in some years. ${ }^{16}$

Finally, we compare the cost efficiency of Sand C-banks using the efficiency ratio (i.e., total overhead expenses as a percentage of net interest income plus non-interest income). Except for banks with at least $\$ 1$ billion of assets, we find that S-banks consistently have lower efficiency ratios than C-banks (implying that S-banks are more cost efficient). Mean values are significantly smaller for S-banks with less than $\$ 300$ million of assets than for C-banks of similar size. We also

\footnotetext{
${ }^{14}$ For banks with assets between $\$ 300$ million and $\$ 1$ billion, this difference is statistically significant in some years between 1997 and 2004. For banks with less than $\$ 300$ million, the difference is statistically significant in every year.

${ }^{15}$ The UBPR makes a tax-equivalent adjustment to net interest income and, hence, to net interest margin, to account for differences in the tax treatment of different assets that banks hold without regard to whether a bank is an S- or C-bank. The implications of this adjustment are examined in a later section.

${ }^{16}$ Because there were very few S-banks with more than $\$ 1$ billion of assets, especially before 2001, differences in the mean values for $\mathrm{S}$ - and C-banks in this size range are not especially interesting.
}

find that S-banks tend to have smaller mean efficiency ratios than C-banks in other years, though the differences are consistently statistically significant only for banks with less than $\$ 100$ million of assets. Hence, it appears that relatively low overhead expenses can account for at least part of the higher profit rates of smaller S-banks as compared with C-banks. For S-banks with between $\$ 100$ million and $\$ 300$ million of assets, we find that both lower overhead expenses and higher net interest margins may play some role; whereas, for S-banks with between $\$ 300$ million and $\$ 1$ billion of assets, a higher net interest margin is more important for explaining the higher profit rates of S-banks. ${ }^{17}$

Taxes may account for some of the tendency for S-banks to have lower overhead expenses than C-banks of similar size, which further suggests caution when comparing either pre-tax or adjusted after-tax profit rates across S- and C-banks. Sbanks are closely held corporations, and their senior managers often own a high percentage of the outstanding stock of the banks they manage. Owner/managers generally prefer to receive income in the form of earnings distributions rather than salary because salary is subject to employment taxes but other distributions are not. S-banks are required to pay reasonable compensation to shareholder-employees, ${ }^{18}$ but the differential tax treatment of salary income and other distributions of S-bank earnings might help explain the tendency for S-banks to have relatively lower overhead expenses, and hence higher pre-tax operating profit rates, than C-banks.

Unfortunately, data on the salaries of shareholder-employees of banks are not available to test for differences in the compensation of owner/ managers of S- and C-banks. The UBPR does provide data on total personnel expenses, however. We test whether lower personnel expenses can explain the higher mean pre-tax operating profit rates of S-banks. Table 5 reports mean values of

\footnotetext{
17 The UBPR does not include data on the efficiency ratio before 2000 . In addition, for banks with between $\$ 300$ million and $\$ 1$ billion of assets, in some years, the differences between mean values for S- and C-banks of net interest margin, and of net pretax operating profit, are not statistically significant.

18 See Hritz (2005).
} 


\section{Table 6}

2004 Performance of C-Banks that Became S-Banks in 2005

\begin{tabular}{|c|c|c|c|c|c|c|}
\hline Bank size group & ROA & ROE & $\begin{array}{c}\text { Pre-tax } \\
\text { operating } \\
\text { profit/assets }\end{array}$ & $\begin{array}{c}\text { Net interest } \\
\text { margin }\end{array}$ & $\begin{array}{c}\text { Cost } \\
\text { efficiency }\end{array}$ & $\begin{array}{l}\text { Number } \\
\text { of banks }\end{array}$ \\
\hline \multicolumn{7}{|c|}{ Performance of C-banks that became S-banks in 2005 (mean values of various performance measures in 2004) } \\
\hline More than $\$ 1$ billion & 1.22 & 13.15 & 1.91 & 4.17 & 62.07 & 3 \\
\hline$\$ 300$ million to $\$ 1$ billion & 1.23 & 14.62 & 1.83 & 4.44 & 58.37 & 9 \\
\hline$\$ 100$ to $\$ 300$ million & 1.06 & 11.06 & 1.55 & 4.38 & 62.79 & 40 \\
\hline$\$ 50$ to $\$ 100$ million & 1.06 & 10.58 & 1.57 & 4.43 & 62.96 & 40 \\
\hline Less than $\$ 50$ million & 0.91 & 8.19 & 1.24 & 4.32 & 70.18 & 35 \\
\hline \multicolumn{7}{|c|}{ Performance of C-banks that did not become S-banks in 2005 (mean values of various performance measures in 2004} \\
\hline More than $\$ 1$ billion & 1.22 & 13.53 & 1.81 & 3.82 & 57.77 & 398 \\
\hline$\$ 300$ million to $\$ 1$ billion & 1.13 & 12.28 & 1.65 & 4.10 & 60.19 & 850 \\
\hline$\$ 100$ to $\$ 300$ million & 1.03 & 10.63 & 1.48 & 4.25 & 63.11 & 1,701 \\
\hline$\$ 50$ to $\$ 100$ million & 0.91 & 8.69 & 1.27 & 4.27 & 67.11 & 1,056 \\
\hline Less than $\$ 50$ million & 0.78 & 6.90 & 1.08 & 4.30 & 71.57 & 923 \\
\hline
\end{tabular}

Means of non-converting banks minus means of converting banks ( $p$-values for hypothesis tests of equal means)

\begin{tabular}{|c|c|c|c|c|c|}
\hline More than $\$ 1$ billion & $\begin{array}{l}0.00 \\
0.35\end{array}$ & $\begin{array}{l}0.38 \\
0.35\end{array}$ & $\begin{array}{r}-0.10 \\
0.33\end{array}$ & $\begin{array}{r}-0.35 \\
0.14\end{array}$ & $\begin{array}{r}-4.29 \\
0.30\end{array}$ \\
\hline$\$ 300$ million to $\$ 1$ billion & $\begin{array}{r}-0.10 \\
0.26\end{array}$ & $\begin{array}{r}-2.34 \\
0.14\end{array}$ & $\begin{array}{r}-0.18 \\
0.23\end{array}$ & $\begin{array}{r}-0.34 \\
0.06\end{array}$ & $\begin{array}{l}1.83 \\
0.30\end{array}$ \\
\hline$\$ 100$ to $\$ 300$ million & $\begin{array}{r}-0.03 \\
0.36\end{array}$ & $\begin{array}{r}-0.43 \\
0.32\end{array}$ & $\begin{array}{r}-0.07 \\
0.30\end{array}$ & $\begin{array}{r}-0.13 \\
0.16\end{array}$ & $\begin{array}{l}0.32 \\
0.39\end{array}$ \\
\hline$\$ 50$ to $\$ 100$ million & $\begin{array}{r}-0.16 \\
0.02\end{array}$ & $\begin{array}{r}-1.89 \\
0.01\end{array}$ & $\begin{array}{r}-0.30 \\
0.00\end{array}$ & $\begin{array}{r}-0.16 \\
0.10\end{array}$ & $\begin{array}{l}4.15 \\
0.03\end{array}$ \\
\hline Less than $\$ 50$ million & $\begin{array}{r}-0.12 \\
0.08\end{array}$ & $\begin{array}{r}-1.28 \\
0.09\end{array}$ & $\begin{array}{r}-0.16 \\
0.12\end{array}$ & $\begin{array}{r}-0.02 \\
0.39\end{array}$ & $\begin{array}{l}1.39 \\
0.32\end{array}$ \\
\hline
\end{tabular}

NOTE: Includes only those banks in peer groups 1 through 15 of the Uniform Bank Performance Report. Data exclude banks with ROA among the largest or smallest 1 percent of observations.

the sum of pre-tax net operating profit (as a percentage of average total assets) plus personnel expenses (also as a percentage of average total assets) for banks in the five size groups. If lower personnel expenses account for the higher pre-tax operating profit of S-banks, we would expect to fail to reject the hypotheses that the mean values of the sum of personnel expenses and pre-tax net operating profit are equal for S- and C-banks. However, we reject the hypothesis at standard significance levels for banks in all size groups, indicating that lower personnel expenses cannot account fully for the higher mean pre-tax operating profit rates of S-banks. ${ }^{19}$

\section{Ex Ante Performance of S-Banks}

We have been unable to identify definitively why S-banks tend to earn more than C-banks of similar size. Therefore, we next investigate the C-banks that have become S-banks and whether

${ }^{19}$ For banks with $\$ 300$ million or more of assets, we cannot reject the hypothesis in some years. However, we always reject the hypothesis for banks with less than $\$ 300$ million of assets. 
Table 7

\section{Means of Non-Converting Banks Minus Means of Converting Banks (p-values for hypothesis tests of equal means)}

\begin{tabular}{|c|c|c|c|c|c|c|c|c|c|c|c|c|}
\hline \multirow[b]{2}{*}{ Bank size group } & \multicolumn{3}{|c|}{2005} & \multicolumn{3}{|c|}{2004} & \multicolumn{3}{|c|}{2003} & \multicolumn{3}{|c|}{2002} \\
\hline & ROA & ROE & $\mathrm{N}^{*}$ & ROA & ROE & $\mathrm{N}^{*}$ & ROA & ROE & $\mathrm{N}^{*}$ & ROA & ROE & $\mathbf{N}^{*}$ \\
\hline More than $\$ 1$ billion & $\begin{array}{l}0.00 \\
0.35\end{array}$ & $\begin{array}{l}0.38 \\
0.35\end{array}$ & 3 & $\begin{array}{l}n / a \\
n / a\end{array}$ & $\begin{array}{l}n / a \\
n / a\end{array}$ & 0 & $\begin{array}{l}n / a \\
n / a\end{array}$ & $\begin{array}{l}n / a \\
n / a\end{array}$ & 0 & $\begin{array}{l}n / a \\
n / a\end{array}$ & $\begin{array}{l}n / a \\
n / a\end{array}$ & 0 \\
\hline$\$ 300$ million to $\$ 1$ billion & $\begin{array}{r}-0.10 \\
0.26\end{array}$ & $\begin{array}{r}-2.34 \\
0.14\end{array}$ & 9 & $\begin{array}{r}-0.06 \\
0.29\end{array}$ & $\begin{array}{l}1.47 \\
0.15\end{array}$ & 7 & $\begin{array}{l}0.02 \\
0.38\end{array}$ & $\begin{array}{l}0.47 \\
0.33\end{array}$ & 14 & $\begin{array}{r}-0.07 \\
0.28\end{array}$ & $\begin{array}{r}-2.23 \\
0.09\end{array}$ & 15 \\
\hline$\$ 100$ to $\$ 300$ million & $\begin{array}{r}-0.03 \\
0.36\end{array}$ & $\begin{array}{r}-0.43 \\
0.32\end{array}$ & 40 & $\begin{array}{r}-0.15 \\
0.01\end{array}$ & $\begin{array}{r}-1.87 \\
0.02\end{array}$ & 39 & $\begin{array}{r}-0.11 \\
0.09\end{array}$ & $\begin{array}{r}-1.39 \\
0.06\end{array}$ & 59 & $\begin{array}{r}-0.02 \\
0.36\end{array}$ & $\begin{array}{r}-0.29 \\
0.36\end{array}$ & 42 \\
\hline$\$ 50$ to $\$ 100$ million & $\begin{array}{r}-0.16 \\
0.02\end{array}$ & $\begin{array}{r}-1.89 \\
0.01\end{array}$ & 40 & $\begin{array}{r}-0.12 \\
0.10\end{array}$ & $\begin{array}{r}-1.53 \\
0.09\end{array}$ & 40 & $\begin{array}{r}-0.23 \\
0.00\end{array}$ & $\begin{array}{r}-2.82 \\
0.00\end{array}$ & 43 & $\begin{array}{r}-0.23 \\
0.00\end{array}$ & $\begin{array}{r}-2.96 \\
0.00\end{array}$ & 66 \\
\hline Less than $\$ 50$ million & $\begin{array}{r}-0.12 \\
0.08\end{array}$ & $\begin{array}{r}-1.28 \\
0.09\end{array}$ & 35 & $\begin{array}{r}-0.27 \\
0.00\end{array}$ & $\begin{array}{r}-3.03 \\
0.00\end{array}$ & 45 & $\begin{array}{r}-0.17 \\
0.03\end{array}$ & $\begin{array}{r}-1.80 \\
0.02\end{array}$ & 54 & $\begin{array}{r}-0.18 \\
0.00\end{array}$ & $\begin{array}{r}-1.99 \\
0.00\end{array}$ & 78 \\
\hline
\end{tabular}

NOTE: $\mathrm{N}^{*}$ : Number of C-banks converting to S-banks in given year. Includes only those banks in peer groups 1 through 15 of the Uniform Bank Performance Report. Data exclude banks with ROA among the largest or smallest 1 percent of observations. Bank size groups are based on total end-of-period assets.

they had higher rates of return than other C-banks before they became S-banks. If so, it would suggest that at least some of the tendency for S-banks to have higher rates of return than C-banks might be due to inherent characteristics rather than their status as S-banks.

Table 6 presents summary data on several financial ratios for banks that converted to Sbanks during 2005. The table reports mean values of various performance measures as of year-end 2004 for C-banks that converted to S-bank status during 2005, as well as for C-banks that remained C-banks in 2005. The table also reports the differences in the mean values for converting and nonconverting banks and $p$-values for tests of the hypothesis that the means of converting and nonconverting banks are equal. Only three banks with more than $\$ 1$ billion of assets became S-banks in 2005. Among smaller banks we find a tendency for converting banks to have had higher rates of return during 2004 than non-converting banks. Converting banks with less than $\$ 100$ million of assets had significantly higher ROA, ROE, and pre-tax operating-profit rates during 2004 than did non-converting banks. Converting S-banks with between $\$ 300$ million and $\$ 1$ billion of assets had significantly higher net interest margins than similar-sized non-converting banks; converting banks with between $\$ 50$ million and \$100 million of assets had significantly lower cost efficiency ratios (i.e., they were more cost efficient).

Table 7 reports data for other years; specifically, the table shows the differences in the mean values of ROA and ROE between non-converting and converting banks in the indicated years. As in Table 6, the mean values used to prepare Table 7 are as of December 31 of the year prior to conversion, and the differences shown are the mean values for non-converting banks less the mean values for converting banks. As shown in the table, the banks that converted to S-bank status in a given year tended to have higher ROA and ROE in the year before they converted to S-bank status than the banks that did not convert; in several cases the differences in the means are statistically significant. Hence, it appears that characteristics other than S-bank status explain at least some of the tendency for S-banks to outearn C-banks of similar size. Banks that choose to switch to S-bank status appear to be systematically different from those of similar size that do not elect S-status. 
Table 7, cont'd

\begin{tabular}{|c|c|c|c|c|c|c|c|c|c|c|c|c|c|c|}
\hline \multicolumn{3}{|c|}{2001} & \multicolumn{3}{|c|}{2000} & \multicolumn{3}{|c|}{1999} & \multicolumn{3}{|c|}{1998} & \multicolumn{3}{|c|}{1997} \\
\hline ROA & ROE & $\mathrm{N}^{*}$ & ROA & ROE & $\mathrm{N}^{*}$ & ROA & ROE & $\mathrm{N}^{*}$ & ROA & ROE & $\mathrm{N}^{*}$ & ROA & ROE & $\mathrm{N}^{*}$ \\
\hline $\begin{array}{l}n / a \\
n / a\end{array}$ & $\begin{array}{l}n / a \\
n / a\end{array}$ & 0 & $\begin{array}{l}n / a \\
n / a\end{array}$ & $\begin{array}{l}n / a \\
n / a\end{array}$ & 0 & $\begin{array}{c}-0.22 \\
\mathrm{n} / \mathrm{a}\end{array}$ & $\begin{array}{c}-1.82 \\
\mathrm{n} / \mathrm{a}\end{array}$ & 1 & $\begin{array}{c}-0.42 \\
\mathrm{n} / \mathrm{a}\end{array}$ & $\begin{array}{c}-1.19 \\
\mathrm{n} / \mathrm{a}\end{array}$ & 1 & $\begin{array}{c}-0.25 \\
\mathrm{n} / \mathrm{a}\end{array}$ & $\begin{array}{c}-1.59 \\
\mathrm{n} / \mathrm{a}\end{array}$ & 1 \\
\hline $\begin{array}{r}-0.08 \\
0.28\end{array}$ & $\begin{array}{r}-0.73 \\
0.34\end{array}$ & 9 & $\begin{array}{r}-0.23 \\
0.14\end{array}$ & $\begin{array}{r}-2.56 \\
0.15\end{array}$ & 3 & $\begin{array}{l}0.27 \\
0.04\end{array}$ & $\begin{array}{l}1.51 \\
0.19\end{array}$ & 5 & $\begin{array}{r}-0.25 \\
0.04\end{array}$ & $\begin{array}{r}-2.96 \\
0.11\end{array}$ & 12 & $\begin{array}{l}0.07 \\
0.37\end{array}$ & $\begin{array}{l}1.66 \\
0.33\end{array}$ & 6 \\
\hline $\begin{array}{r}-0.14 \\
0.06\end{array}$ & $\begin{array}{r}-1.05 \\
0.20\end{array}$ & 41 & $\begin{array}{r}-0.04 \\
0.29\end{array}$ & $\begin{array}{r}-0.31 \\
0.35\end{array}$ & 37 & $\begin{array}{r}-0.05 \\
0.25\end{array}$ & $\begin{array}{r}-0.58 \\
0.26\end{array}$ & 58 & $\begin{array}{r}-0.09 \\
0.07\end{array}$ & $\begin{array}{r}-0.54 \\
0.24\end{array}$ & 75 & $\begin{array}{r}-0.19 \\
0.00\end{array}$ & $\begin{array}{r}-1.92 \\
0.00\end{array}$ & 86 \\
\hline $\begin{array}{r}-0.22 \\
0.00\end{array}$ & $\begin{array}{r}-2.17 \\
0.00\end{array}$ & 58 & $\begin{array}{r}-0.10 \\
0.16\end{array}$ & $\begin{array}{r}-0.69 \\
0.27\end{array}$ & 55 & $\begin{array}{r}-0.10 \\
0.02\end{array}$ & $\begin{array}{r}-2.06 \\
0.00\end{array}$ & 90 & $\begin{array}{r}-0.17 \\
0.00\end{array}$ & $\begin{array}{r}-1.76 \\
0.00\end{array}$ & 131 & $\begin{array}{r}-0.17 \\
0.00\end{array}$ & $\begin{array}{r}-2.68 \\
0.00\end{array}$ & 174 \\
\hline $\begin{array}{r}-0.18 \\
0.00\end{array}$ & $\begin{array}{r}-2.27 \\
0.00\end{array}$ & 96 & $\begin{array}{r}-0.21 \\
0.00\end{array}$ & $\begin{array}{r}-1.72 \\
0.00\end{array}$ & 93 & $\begin{array}{r}-0.18 \\
0.00\end{array}$ & $\begin{array}{r}-1.78 \\
0.00\end{array}$ & 109 & $\begin{array}{r}-0.14 \\
0.00\end{array}$ & $\begin{array}{r}-1.61 \\
0.00\end{array}$ & 224 & $\begin{array}{r}-0.18 \\
0.00\end{array}$ & $\begin{array}{r}-1.93 \\
0.00\end{array}$ & 299 \\
\hline
\end{tabular}

PRE-TAX EARNINGS AS AN ALTERNATIVE EARNINGS MEASURE

The pitfalls of comparing banks on the basis of after-tax measures of return caused by the proliferation of S-banks have led some analysts and regulators to use pre-tax profit measures. For example, the FDIC uses income before taxes and extraordinary charges (as a percentage of total assets) in its statistical model designed to identify banks whose financial condition has deteriorated significantly since its last on-site examination (Collier et al., 2003). ${ }^{20}$ Presumably, however, banks seek to maximize after-tax profit, and pretax profit is not necessarily a good measure of a bank's performance. Many banks invest substantial proportions of their assets in securities that yield tax-exempt income. By holding large amounts of tax-advantaged securities, a bank could appear relatively unprofitable on a pre-tax basis but highly profitable on an after-tax basis.

${ }^{20}$ The Federal Reserve uses a similar model (Board of Governors of the Federal Reserve System, 2006). See also Whalen (2005).
The UBPR includes an adjustment to make pre-tax operating profits more comparable across banks with different mixes of taxable and taxexempt securities. ${ }^{21}$ Figure 4 shows the impact of this adjustment on median pre-tax net operating income divided by average total assets for large and small banks, where, as before, large banks are defined as those with $\$ 1$ billion or more of assets and small banks are those with less than $\$ 1$ billion of assets. The figure shows that over the 10-year period from 1996 to 2005, the median pre-tax net operating-income rate of large banks consistently exceeded that of small banks. Further, the figure shows the impact of the adjustment of pre-tax operating income rates for tax-exempt income. The dotted lines show median pre-tax net operating income rates with the adjustment for taxexempt income. Over the 10-year period, the adjustment contributed between 0.06 and 0.10 percentage points to the median rate for large banks and between 0.10 and 0.13 percentage

\footnotetext{
${ }^{21}$ Pre-tax net operating income (TE) equals net interest income (on a tax-equivalent basis) plus non-interest income and realized gains (or losses) on securities, less non-interest expenses, provisions for loan and lease-financing receivables losses, and provisions for allocated transfer risk. See FFIEC (2006, Section III, p. 4).
} 


\section{Figure 4}

\section{Impact of Adjustment for Tax-Exempt Income on Pre-Tax Net Operating Income/Assets}

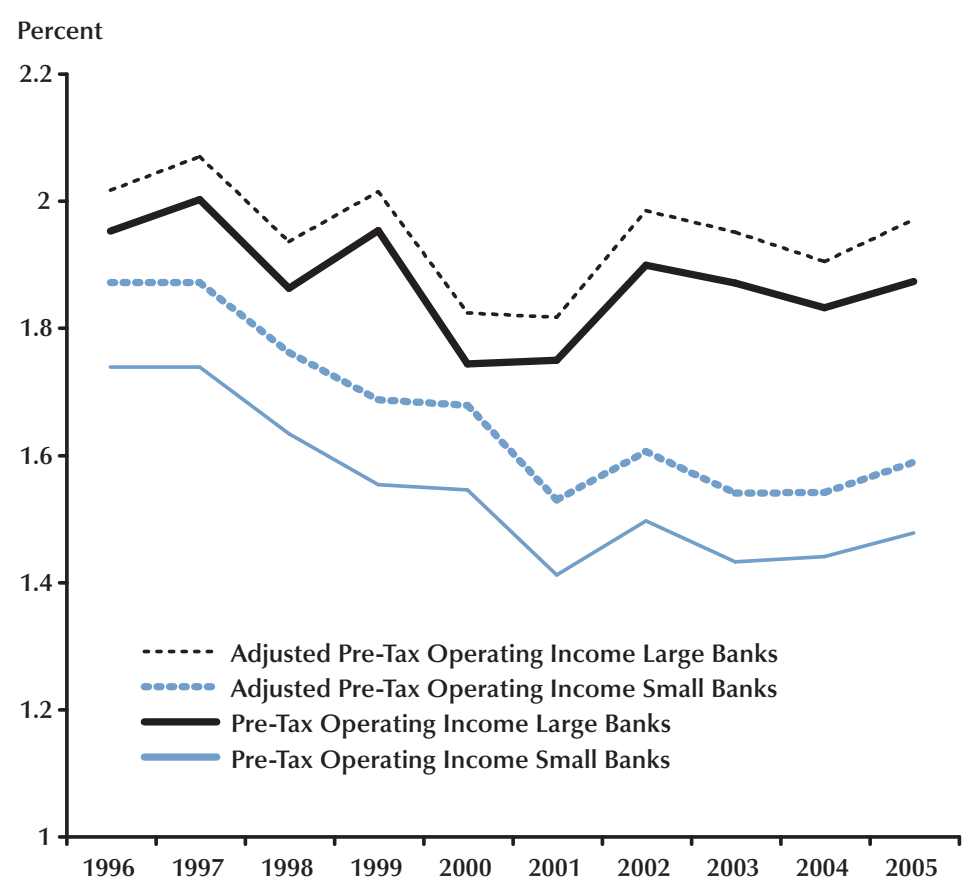

points to the median rate for small banks.

Although the impact of the adjustment on pre-tax net operating-income rates has typically been somewhat larger for small banks than for large banks, the adjustment added approximately 0.10 percentage points to the median pre-tax net operating-income rates of both large and small banks in 2005.

\section{CONCLUSIONS}

The proliferation of banks that elect subchapter $\mathrm{S}$ tax treatment has greatly complicated the meaningful comparison of banks on the basis of after-tax rates of return. Because S-bank earnings are not subject to the federal corporate income tax, S-banks generally have higher aftertax rates of return than other commercial banks (i.e., C-banks). However, S-bank shareholders face a personal income tax liability for their pro rata share of the bank's entire earnings-not just the portion distributed as dividends. S-banks have proliferated, however, because the dividends that they pay to shareholders are not taxed twice. S-banks are permitted to have no more than 100 shareholders, which generally restricts the election of S-status to small banks that do not anticipate rapid growth and whose shares do not trade publicly.

In an attempt to make after-tax earnings rates of S-banks comparable with those of C-banks, the Uniform Bank Performance Report produced by the Federal Financial Institutions Examination Council includes estimates of the federal corporate income taxes that S-banks would pay if subject to that tax. Using these estimates, this article shows that the different federal tax treatments of S- and C-banks has a quantitatively large impact on comparisons of mean after-tax profit rates across banks. Because most S-banks are smaller institutions, comparisons of mean after-tax rates of return across groups of different-size banks are especially problematic. If S-bank earnings are not 
adjusted to make them comparable with C-bank earnings, we find that mean earnings rates of groups of best-practice small banks compare favorably with mean earnings rates of large banks, similar to the results of DeYoung, Hunter, and Udell (2004). However, we also find that mean earnings rates of best-practice small banks are considerably lower if S-bank earnings are adjusted by estimates of federal income taxes, indicating that conclusions of studies that use net after-tax income as a measure of performance can be affected markedly by whether or not S-bank earnings rates are adjusted for taxes.

Our research also finds that S-banks tend to have higher rates of return than C-banks of similar size even when S-bank earnings rates are adjusted by the UBPR estimates of their hypothetical federal corporate income taxes. Smaller S-banks also tend to have higher pre-tax net operating income rates than similar-sized C-banks, mainly because of lower expenses and higher ratios of net noninterest income to assets, whereas larger S-banks tend to have higher net interest margins than Cbanks of similar size. Owner/managers of S-banks generally prefer to receive income in the form of distributed earnings, rather than salary, to limit employment taxes. However, we find that lower personnel expenses do not explain fully the tendency for S-banks to have higher pre-tax net operating income rates than C-banks. Finally, we find that C-banks that became S-banks in a given year tended to have higher after-tax rates of return than other C-banks in the year before they became an S-bank. This result suggests that characteristics other than election of subchapter $S$ tax status account for some of the tendency for S-banks to out-earn C-banks. The banks that choose S-bank tax status appear to be systematically different from other banks of similar asset size.

The growth in the number of banks electing subchapter $\mathrm{S}$ tax treatment has seriously compromised the usefulness of standard after-tax return measures, such as ROA and ROE, for comparing profit rates across banks, and undoubtedly explains the increasing use of pre-tax earnings measures in studies of bank performance. Our study does not show that any particular measure of return is superior for comparing the profit rates of different banks, as the ideal measure largely depends on the question at hand. The evidence reported here indicates that researchers and other analysts should exercise caution when using any profit measure to evaluate bank performance, however, particularly in light of the proliferation of S-banks.

\section{REFERENCES}

Bassett, William F. and Brady, Thomas F. "The Economic Performance of Small Banks, 1985-2000.” Federal Reserve Bulletin, November 2001, 87(11), pp. 719-28.

Board of Governors of the Federal Reserve System. Commercial Bank Examination Manual. Washington, DC: 2006; www.federalreserve.gov/boarddocs/SupManual.

Collier, Charles; Forbush, Sean; Nuxoll, Daniel A. and O'Keefe, John. “The SCOR System of Off-Site Monitoring: Its Objectives, Functioning, and Performance." FDIC Banking Review, 2003, 15(3), pp. 17-32.

DeYoung, Robert; Hunter, William C. and Udell, Gregory F. "The Past, Present, and Probable Future for Community Banks." Journal of Financial Services Research, April/June 2004, 25(2/3), pp. 85-133.

Federal Financial Institutions Examination Council. A User's Guide for the Uniform Bank Performance Report. Arlington, VA: March 2006.

Harvey, James and Padget, Jane. "Subchapter SA New Tool for Enhancing the Value of Community Banks." Federal Reserve Bank of Kansas City Financial Industry Perspectives, December 2000, pp. 17-31.

Hein, Scott E.; Koch, Timothy W. and MacDonald, S. Scott. "On the Uniqueness of Community Banks." Federal Reserve Bank of Atlanta Economic Review, First Quarter 2005, 90(1), pp. 15-36.

Hritz, Steven R. "Reasonable Compensation and SE Taxes.” Tax Advisor, October 2005, pp. 608-10. 


\section{Gilbert and Wheelock}

Keeton, William; Harvey, James and Willis, Paul. "The Role of Community Banks in the U.S.

Economy." Federal Reserve Bank of Kansas City

Economic Review, Second Quarter 2003, 88(2),

pp. 15-43.

Landau, Zev. "Recent Reform and Simplifications for S Corporations." CPA Journal, November 2005, 75(11), pp. 46-50.

Whalen, Gary. "A Hazard Model of CAMELS Downgrades of Low-Risk Community Banks." Working Paper No. 2005-1, Office of the Comptroller of the Currency, May 2005. 